\title{
N-Fertilizer (Urea) Enhances the Phytoextraction of Cadmium through Solanum nigrum L.
}

\author{
Arosha Maqbool ${ }^{1}$, Shafaqat Ali ${ }^{1,2, *}{ }^{\mathbb{C}}$, Muhammad Rizwan ${ }^{1}{ }^{(0)}$, Muhammad Saleem Arif ${ }^{1}$, \\ Tahira Yasmeen ${ }^{1}$, Muhammad Riaz ${ }^{1}$, Afzal Hussain ${ }^{1,3}$, Shamaila Noreen ${ }^{1}$, \\ Mohamed M. Abdel-Daim 4,5 iD and Saad Alkahtani 4 \\ 1 Department of Environmental Science and Engineering, Government College University Faisalabad, \\ Faisalabad 38000, Pakistan; aroshamaqbool@gmail.com (A.M.); mrazi1532@yahoo.com (M.R.); \\ msarif@outlook.com (M.S.A.); rida_akash@hotmail.com (T.Y.); mr548@ymail.com (M.R.); \\ afzaalh345@gmail.com (A.H.); shamailanoureen@gcuf.edu.pk (S.N.) \\ 2 Department of Biological Sciences and Technology, China Medical University, Taichung 40402, Taiwan \\ 3 Department of Environmental Sciences, The University of Lahore, Lahore 54000, Pakistan \\ 4 Department of Zoology, College of Science, King Saud University, P.O. Box 2455, Riyadh 11451, Saudi Arabia; \\ abdeldaim.m@vet.suez.edu.eg (M.M.A.-D.); salkahtani@ksu.edu.sa (S.A.) \\ 5 Pharmacology Department, Faculty of Veterinary Medicine, Suez Canal University, Ismailia 41522, Egypt \\ * Correspondence: shafaqataligill@yahoo.com
}

Received: 18 April 2020; Accepted: 18 May 2020; Published: 29 May 2020

\begin{abstract}
Heavy metal contamination is currently a major environmental concern, as most agricultural land is being polluted from municipal discharge. Among various other pollutants, cadmium $(\mathrm{Cd})$, one of the most harmful heavy metals, enters into the food chain through the irrigation of crops with an industrial effluent. In the present study, a pot experiment was designed to assess the effect of different nitrogen $(\mathrm{N})$-fertilizer forms in the phytoremediation of $\mathrm{Cd}$ through Solanum nigrum $\mathrm{L}$. Two types of $\mathrm{N}$ fertilizers $\left(\mathrm{NH}_{4} \mathrm{NO}_{3}\right.$ and urea) were applied to the soil in different ratios (0:0, 100:0, 0:100, and 50:50 of $\mathrm{NH}_{4} \mathrm{NO}_{3}$ and urea, individually) along with different $\mathrm{Cd}$ levels $\left(0,25\right.$, and $\left.50 \mathrm{mg} \mathrm{kg}^{-1}\right)$. The plants were harvested 70 days after sowing the seeds in pots. Cadmium contamination significantly inhibited the growth of leaves and roots of S. nigrum plants. Cadmium contamination also induced oxidative stress; however, the application of $\mathrm{N}$-fertilizers increased the plant biomass by inhibiting oxidative stress and enhancing antioxidants' enzymatic activities. The greatest plant growth was observed in the urea-treated plants compared with the $\mathrm{NH}_{4} \mathrm{NO}_{3}$-treated plants. In addition, urea-fed plants also accumulated higher $\mathrm{Cd}$ concentrations than $\mathrm{NH}_{4} \mathrm{NO}_{3}$-fed plants. It is concluded that urea is helpful for better growth of S. nigrum under Cd stress. Thus, an optimum concentration of $\mathrm{N}$-fertilizers might be effective in the phytoremediation of heavy metals through S. nigrum.
\end{abstract}

Keywords: N-fertilizers; toxicity; phytoremediation; antioxidants; metal uptake

\section{Introduction}

Anthropogenic activities have resulted in environmental degradation and a significant reduction in soil productivity [1]. Abiotic stress, such as heavy metals, extreme temperature, and salinity, affect crop production [2]. Industrial discharge, sewage sludge, mining, and agriculture have become major precursors of heavy metal discharge into water bodies and soil [3]. Compared with all other heavy metals, cadmium (Cd) is considered lethal once it becomes part of the food cycle.

Around $70 \%$ of the dietary intake of $\mathrm{Cd}$ occurs from consuming the vegetables and grain crops grown in Cd-contaminated soils [4]. Cadmium is highly toxic for plant growth and seed germination, in addition to the antioxidant, photosynthetic, and enzyme activities [5]. It also causes visual toxicity 
symptoms including a reduction in plant height, necrosis, and leaf chlorosis [6]. Excessive concentration of $\mathrm{Cd}$ also impairs the uptake of some integral nutrients, such as iron, zinc, and manganese [7]. Increased electrolyte leakage (EL), malondialdehyde (MDA) content, and oxidative stress in plants, along with a reduced enzyme activity, are also evident in Cd-affected plants [8]. Therefore, it is imperative to control $\mathrm{Cd}$ pollution so as to minimize the $\mathrm{Cd}$ concentrations in the soil, as well as to reduce its uptake by plants, especially in the edible portions of plants [9]. Phytoremediation is a useful technique to cope with the heavy metals problem, through use of green plants to remove/degrade pollutants from the contaminated soils. Phytoremediation is considered an attractive substitute for soil remediation, because it is one of the cheapest and most ecofriendly methods compared with other techniques [10].

Different plants accumulate heavy metals when grown in a metal contaminated soil; an example of such an uptake is the Cd taken up by Brassica oleracea L. [11]. In addition, various hyperaccumulator plants can help to remediate the highly metal-polluted soils. A number of Cd-hyperaccumulator plant species have been reported, including S. nigrum [12], Malva rotundifolia [13], Bidens pilosa [14], Noccaea caerulescens [15], Sedum alfredii [16], and Jatropha curcas [17]. Among these Cd hyperaccumulators, S. nigrum is considered more efficient for its fast growth and higher tolerance to $\mathrm{Cd}$, without compromising biomass production [9]. However, the growth of S. nigrum may be negatively affected at higher $\mathrm{Cd}$ concentrations, which require some amendments, especially in the early growth stages, in order to improve the phytoextraction used by this plant.

The application of $\mathrm{N}$-fertilizers is considered an effective measure to improve the soil fertility and phytoremediation efficiency of hyperaccumulator plants [18]. Nitrogen is an integral component of plants that makes various secondary metabolites, and is also helpful in chlorophyll, which is a key component of photosynthesis $[19,20]$. Numerous effects of $\mathrm{N}$ fertilization on soil-Cd dynamics have been observed, including desorption and adsorption, chemical transformation, dilution effect, and transportation, which ultimately influence $\mathrm{Cd}$ uptake by plants [21]. Many studies have shown that the addition of different $\mathrm{N}$ compounds $\left(\mathrm{NH}_{4}\right.$ and $\left.\mathrm{NO}_{3}\right)$ in different combinations and dosages affect plant growth and biomass [22-26].

The study was designed to evaluate the effect of various $\mathrm{N}$-fertilizers on the phytoremediation of $\mathrm{Cd}$ through S. nigrum by measuring changes in plant growth, chlorophyll and carotenoid contents, photosynthetic parameters, oxidative stress, and antioxidant enzyme activities under different $\mathrm{N}$ fertilizer combinations and Cd contamination levels.

\section{Materials and Methods}

\subsection{Experimental Design}

A pot experiment was conducted in a botanical garden located in Government College University Faisalabad (Faisalabad, Pakistan; $31^{\circ} 25^{\prime} 0^{\prime \prime} \mathrm{N}, 73^{\circ} 5^{\prime} 28^{\prime \prime} \mathrm{E}$ ). The soil texture was measured by the method of Bouyoucos [27]; the $\mathrm{pH}$ and electrical conductivity (EC) with $\mathrm{pH}$ and EC meters, respectively; organic carbon was measured using the Walkley-Black method [28]; and the sodium absorption ratio (SAR) and soluble ions were measured using the method described by Page et al. [29]. The soil physicochemical characteristics are shown in Table 1 . The soil was spiked and entirely mixed with different $\mathrm{Cd}\left(\mathrm{CdCl}_{2}\right.$ $\left.2.5 \mathrm{H}_{2} \mathrm{O}\right)$ levels $\left(0,25\right.$, and $\left.50 \mathrm{mg} \mathrm{kg}^{-1}\right)$. Nitrogen fertilizers of two different kinds $\left(\mathrm{NH}_{4} \mathrm{NO}_{3}\right.$ and urea) with varying ratios $\left(0-0,100-0,0-100\right.$, and $\left.50-50 \mathrm{mg} \mathrm{kg}^{-1}\right)$ were added into the soil. It is noteworthy that the contents for $\mathrm{Cd}, \mathrm{Pb}, \mathrm{Cu}$, and $\mathrm{Zn}$ were fundamentally low and unnoticeable in these fertilizers. 
Table 1. Soil physicochemical properties used for the experiment.

\begin{tabular}{|c|c|}
\hline Texture & Sandy Loam \\
\hline Silt & $14.72 \%$ \\
\hline Sand & $68.07 \%$ \\
\hline Clay & $17.21 \%$ \\
\hline EC & $1.83 \mathrm{dS} \mathrm{m}^{-1}$ \\
\hline $\mathrm{pH}$ & 7.72 \\
\hline SAR & $1.93\left(\mathrm{mmol} \mathrm{L}^{-1}\right)^{1 / 2}$ \\
\hline Available P & $2.20 \mathrm{mg} \mathrm{kg}^{-1}$ \\
\hline Organic matter & $0.64 \%$ \\
\hline $\mathrm{HCO}_{3}{ }^{-1}$ & $2.58 \mathrm{mmol} \mathrm{L}^{-1}$ \\
\hline $\mathrm{SO}_{4}^{-2}$ & $11.69 \mathrm{mmol} \mathrm{L}^{-1}$ \\
\hline $\mathrm{Cl}^{-}$ & $5.35 \mathrm{mmol} \mathrm{L}^{-1}$ \\
\hline $\mathrm{Ca}^{2+}+\mathrm{Mg}^{2+}$ & $14.26 \mathrm{mmol} \mathrm{L}^{-1}$ \\
\hline $\mathrm{K}^{+}$ & $0.03 \mathrm{mmol} \mathrm{L}^{-1}$ \\
\hline $\mathrm{Na}^{+}$ & $5.48 \mathrm{mmol} \mathrm{L}^{-1}$ \\
\hline Available $\mathrm{Zn}^{2+}$ & $0.81 \mathrm{mg} \mathrm{kg}^{-1}$ \\
\hline Available $\mathrm{Cu}^{2+}$ & $0.34 \mathrm{mg} \mathrm{kg}^{-1}$ \\
\hline Available $\mathrm{Cd}^{2+}$ & $0.09 \mathrm{mg} \mathrm{kg}^{-1}$ \\
\hline
\end{tabular}

\subsection{Soil Pot Experiments}

In this study, $5 \%$ sodium hypochlorite $(\mathrm{NaClO})$ was applied for $10 \mathrm{~min}$ in order to sterilize the S. nigrum seeds, which were then washed four times with deionized water. The washed and blot-dried seeds were planted in a plastic tray filled with sand, and half-strength Hoagland solution was applied. After three weeks of germination, the uniform seedlings were transferred into pots (four seedlings in each pot). Every single pot was filled with $5 \mathrm{~kg}$ of soil. All of the pots were set following complete randomized design (CRD) with four repeats for each treatment, and the water was topped up with tap water in order to maintain the $70 \%$ soil water-holding limit.

\subsection{Plant Harvesting}

The plants were harvested 70 days after sowing the seeds and were sectioned into shoots and roots. The length of the roots and shoots, numbers of leaves, leaf area, and fresh weight of plants were measured. The root and shoot samples were further dried in an oven for $72 \mathrm{~h}$ at $70{ }^{\circ} \mathrm{C}$, and the dry weights were measured.

\subsection{Determination of Photosynthetic, Chlorophyll, and Carotenoid Content Parameters}

Fresh leaf samples $(0.5 \mathrm{~g})$ were soaked in acetone $(85 \%, v / v$, Sigma) and placed in the dark. The soaked samples were centrifuged $\left(4000 \times g\right.$ for $\left.10 \mathrm{~min}, 4^{\circ} \mathrm{C}\right)$ and the supernatant was collected. Data were recorded on a spectrophotometer at wavelengths of 470,647 , and $664.5 \mathrm{~nm}$, separately. The chlorophyll content, i.e., chlorophyll a, chlorophyll b, and total chlorophyll, and carotenoids were recorded [30]. On a sunny day (10:00 a.m. to 12:00 p.m.), an infrared gas analyzer (IRGA) was used for the assessment of the conductance of the stomata water-use efficiency, rate of transpiration, and photosynthetic rate in the plants' leaves.

\subsection{Determination of EL, $M D A, \mathrm{H}_{2} \mathrm{O}_{2}$, and Antioxidant Enzyme Concentration}

The measurement of both the oxidative stress markers and the activities of antioxidant enzymes were done 70 days after seed sowing. The shoot and root samples were placed in glass tubes vertically and heated at $32{ }^{\circ} \mathrm{C}$ for $2 \mathrm{~h}$ in distilled water of a known volume in order to measure the electrolyte leakage. This solution was termed $\mathrm{EC}_{1}$. Then, the same solution was heated at $121^{\circ} \mathrm{C}$ for $20 \mathrm{~min}$, 
and EC of this second solution was recorded and named $\mathrm{EC}_{2}$. The Dionisio-Sese and Tobita [31] equation was used to estimate the EL content.

For the estimation of the $\mathrm{H}_{2} \mathrm{O}_{2}$ content, a phosphate buffer solution ( $3.0 \mathrm{~mL}$ ) was added to the sample (50 mg) and centrifuged at $6000 \times g$ for $30 \mathrm{~min}$, keeping the temperature at $4{ }^{\circ} \mathrm{C}$. Then, $1 \mathrm{~mL}$ of titanium sulfate $(0.1 \%)$ was mixed in a supernatant and centrifuged at $6000 \times g$ for $20 \mathrm{~min}$ at $4{ }^{\circ} \mathrm{C}$. Absorption was determined at a wavelength of $410 \mathrm{~nm}$ and a coefficient of extinction for $\mathrm{H}_{2} \mathrm{O}_{2}$ of $0.28 \mu \mathrm{mol}^{-1} \mathrm{~cm}^{-1}$. The peroxidase (POD), catalase (CAT), superoxide dismutase (SOD), and ascorbate peroxidase (APX) enzyme activities were determined following the recommendations of Zhang [32] and Aebi [33]. The samples were prepared in a phosphate buffer $(0.05 \mathrm{mmol})$ and the supernatant was gained through centrifuging for $10 \mathrm{~min}$ at $12,000 \times \mathrm{g}$ and $4{ }^{\circ} \mathrm{C}$.

\subsection{Cadmium Determination in Plants, Translocation Factor and Bioaccumulation Factor}

Crushed root and shoot samples were digested using $\mathrm{HNO}_{3}-\mathrm{HClO}_{4}(3: 1, v / v)$. The samples were kept in $65 \% \mathrm{HNO}_{3}-\mathrm{HClO}_{4}(3: 1, v / v)$ for one night and then put on a hot plate after adding $\mathrm{HNO}_{3}(5.0 \mathrm{~mL})$. The clear solution obtained after digestion was filtered and the $\mathrm{Cd}$ concentration was measured using an atomic absorption spectrophotometer. Translocation factor (TF) was calculated by using Equation (1):

$$
\mathrm{TF}=\mathrm{Cd}(\text { Plant shoot }) / \mathrm{Cd} \text { (Plant root) }
$$

and the bioaccumulation factor (BCF) was calculated using Equation (2):

$$
\mathrm{TF}=\mathrm{Cd} \text { concentration in root/Total Cd concentration in soil }
$$

\subsection{Statistical Analysis}

A two-way analysis of variance test (ANOVA) was applied in order to test the significance of the $\mathrm{N}$ fertilizers and $\mathrm{Cd}$ concentrations. Tukey's posthoc test was applied for the multiple means comparison technique. The statistical analysis was performed with SPSS for Windows Software v. 19 (IBM, Armonk, NY, USA).

\section{Results}

\subsection{Assessment of N-Fertilizer on Growth and Biomass}

Stunted growth was observed in the control group, while no such signs were observed in the $\mathrm{N}$-fertilizer-treated group (Figure 1). The roots' and shoots' dry weight, the number of leaves per plant shoot length and root length, and the leaf area of the S. nigrum plants significantly increased in the $\mathrm{N}$-fertilizer treatments (Figure 1). A maximum plant growth was observed in the urea-treated plants at a $\mathrm{Cd}$ level $\left(0 \mathrm{mg} \mathrm{kg}{ }^{-1}\right)$, with respect to the $\mathrm{NH}_{4} \mathrm{NO}_{3}$-treated and control plants. In addition, more leaves were observed in the urea-treated plants compared with the $\mathrm{NH}_{4} \mathrm{NO}_{3}$-treated plants (Figure 1).

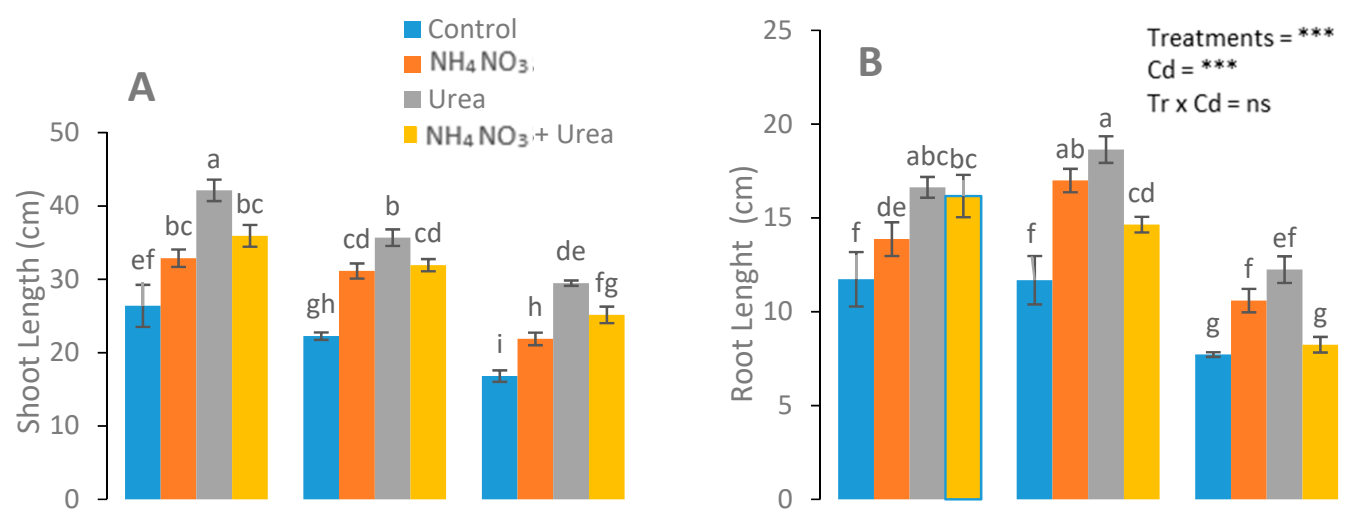

Figure 1. Cont. 

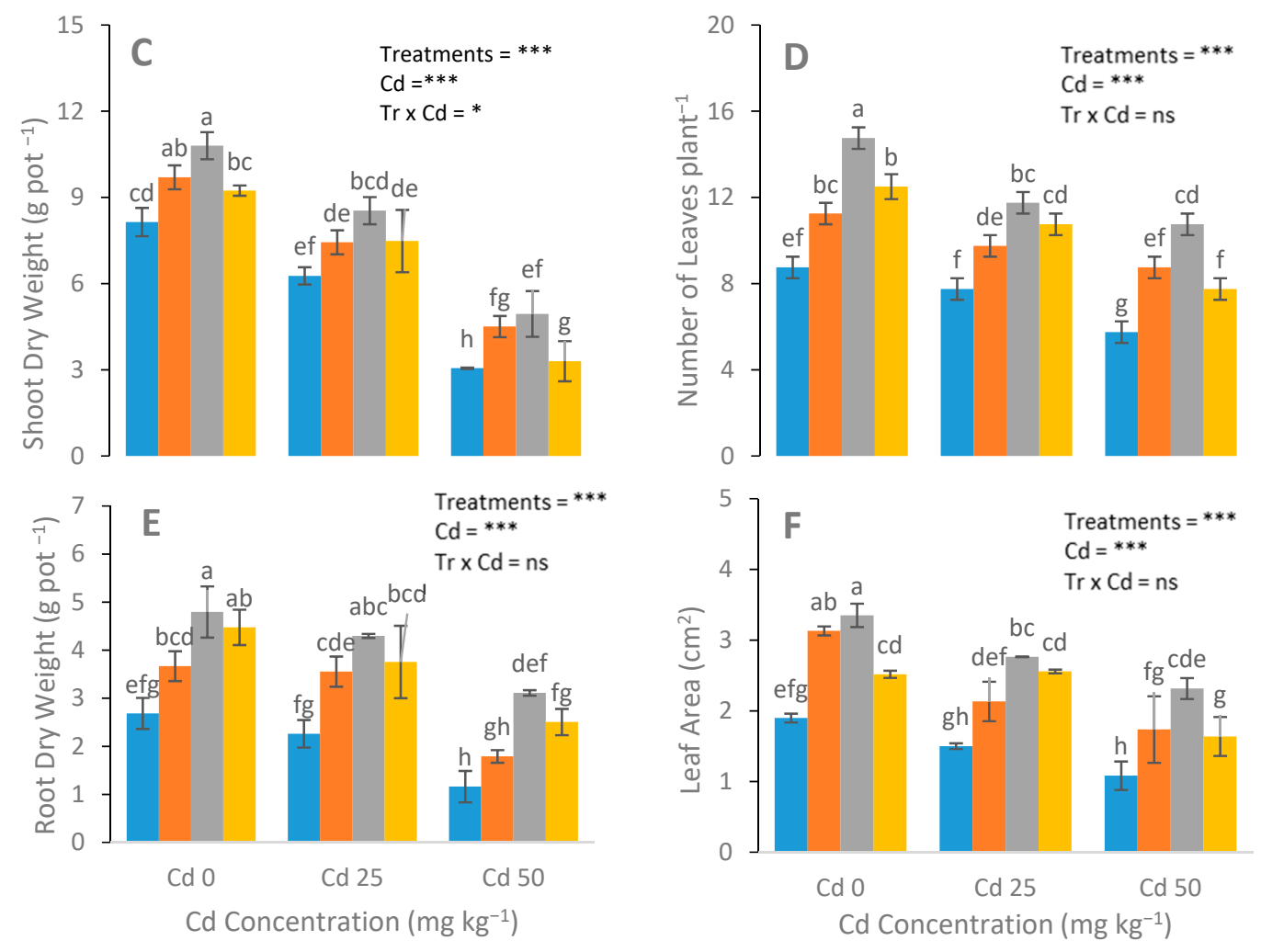

Figure 1. Effect of the $\mathrm{Cd}\left(0,25\right.$, and $\left.50 \mathrm{mg} \mathrm{kg}^{-1}\right)$ and $\mathrm{N}$ fertilizers (ratios of 0:0, 100:0, 0:100, and 50:50 mg kg ${ }^{-1}$ urea, $\mathrm{NH}_{4} \mathrm{NO}_{3}$, and urea $+\mathrm{NH}_{4} \mathrm{NO}_{3}$ ) on shoot length (A), root length (B), shoot dry weight (C), number of leaves (D), root dry weight (E), and leaf area (F) of S. nigrum. Different letters show a significance difference at $p<0.05$ along with $n=4$.

\subsection{Assessment of Gas Exchange, Chlorophyll, and Carotenoid Content Attributes}

Differential responses of chlorophyll and gas exchange attributes were recorded in urea-treated and $\mathrm{NH}_{4} \mathrm{NO}_{3}$-treated plants. Significant changes with the maximum values of $\mathrm{Chl} a, \mathrm{Chl} b$, total $\mathrm{Chl}$, and carotenoid contents were observed in the urea-fed plants (Figure 2). A nonsignificant increase in chlorophyll content was observed in the urea-treated plants at $25 \mathrm{mg} \mathrm{kg}^{-1} \mathrm{Cd}$ concentrations, in contrast to the $\mathrm{NH}_{4} \mathrm{NO}_{3}$-treated and control plants. In addition, a higher expression of gas attributes was recorded in the urea-treated plants than that of the $\mathrm{NH}_{4} \mathrm{NO}_{3}$-fed plants (Figure 3).
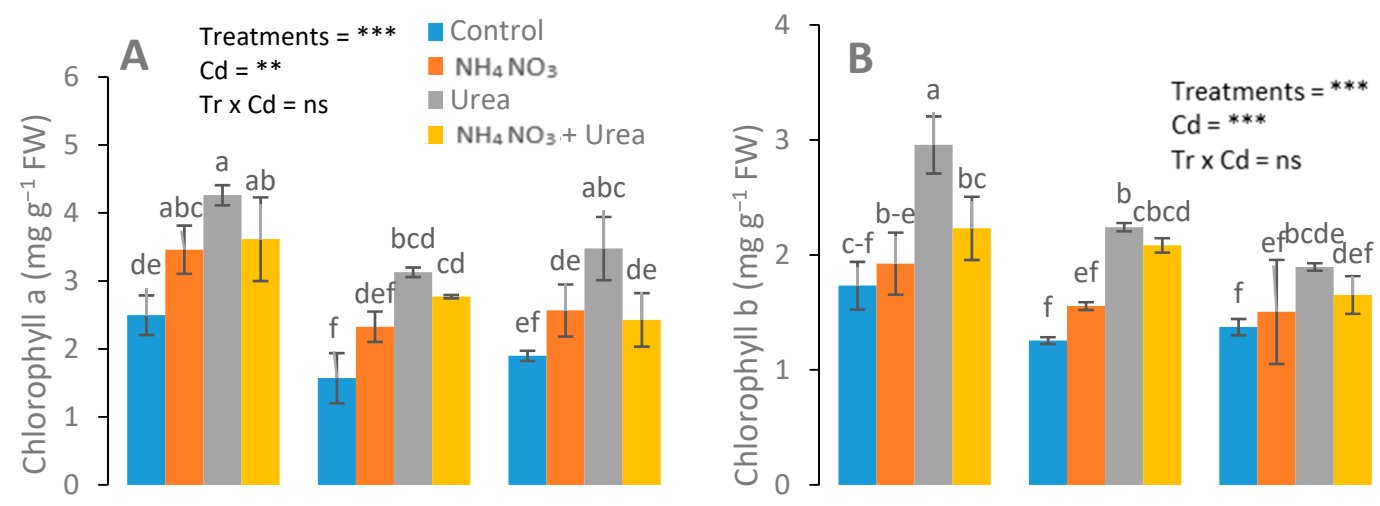

Figure 2. Cont. 


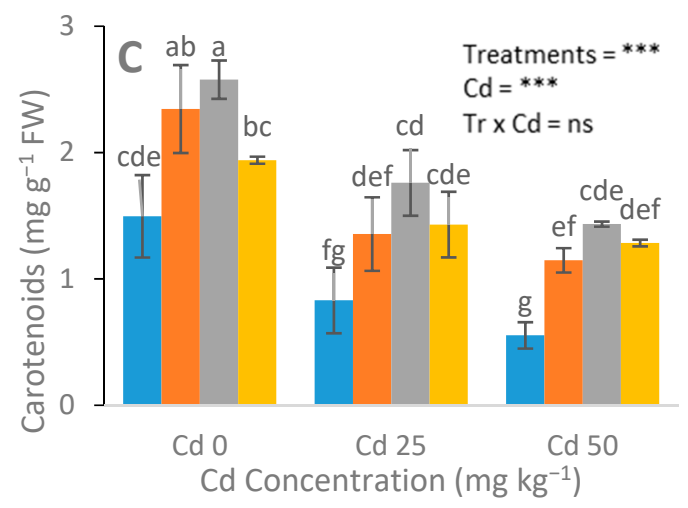

Figure 2. Effects of $\mathrm{Cd}\left(0,25\right.$, and $\left.50 \mathrm{mg} \mathrm{kg}^{-1}\right)$ and $\mathrm{N}$ fertilizers (ratios of 0:0, 100:0, 0:100, and 50:50 mg kg ${ }^{-1}$ urea, $\mathrm{NH}_{4} \mathrm{NO}_{3}$, and urea $+\mathrm{NH}_{4} \mathrm{NO}_{3}$ ) on chlorophyll a (A), chlorophyll b (B), and carotenoid (C) of S. nigrum. Different letters show a significance difference at $p<0.05$ along with $n=4$.
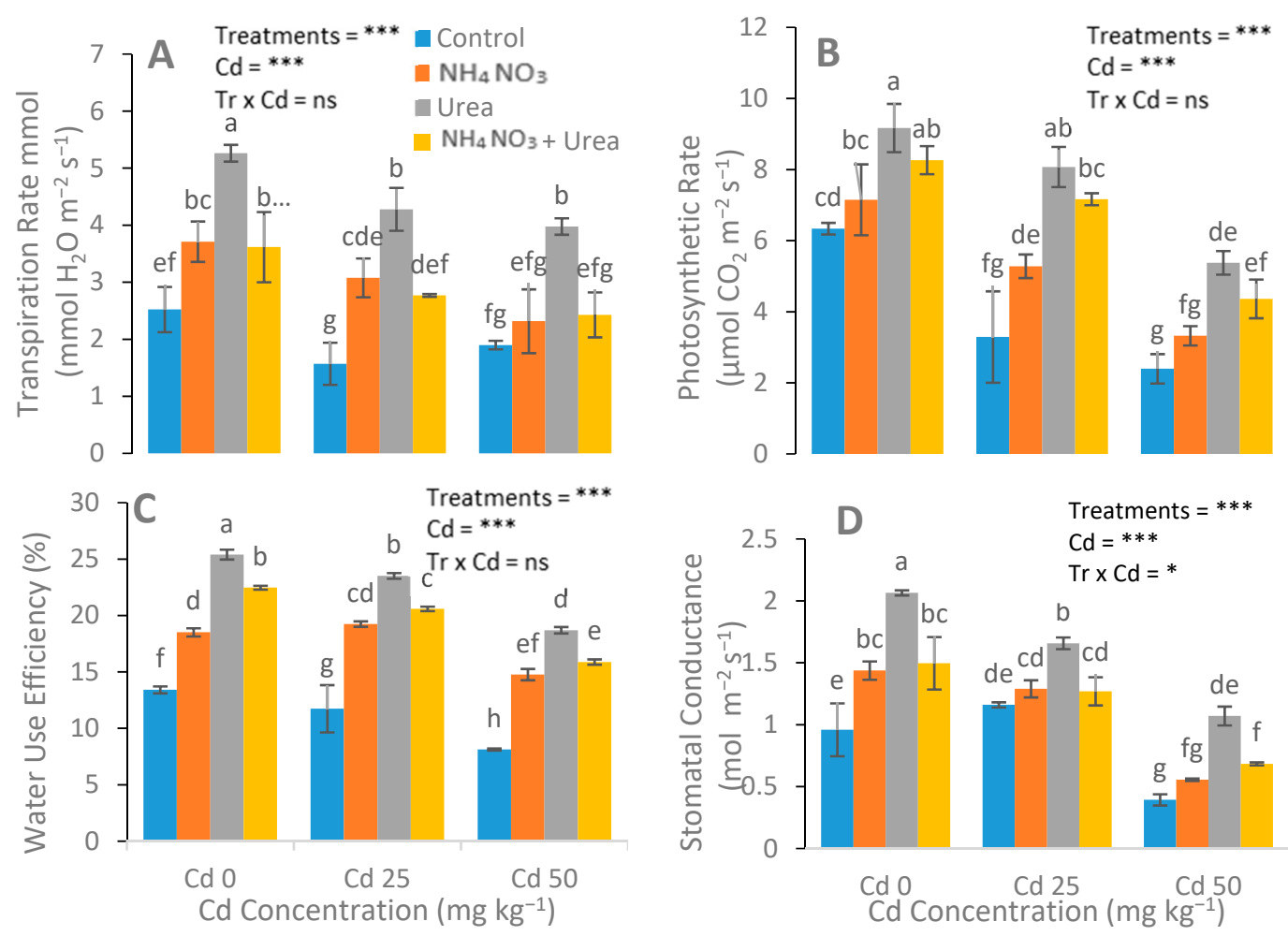

Figure 3. Effects of Cd stress $\left(0,25\right.$, and $\left.50 \mathrm{mg} \mathrm{kg}^{-1}\right)$ and $\mathrm{N}$ fertilizers (ratios of 0:0, 100:0, 0:100, and 50:50 mg kg${ }^{-1}$ urea, $\mathrm{NH}_{4} \mathrm{NO}_{3}$, and urea $+\mathrm{NH}_{4} \mathrm{NO}_{3}$ ) on the transpiration rate (A), photosynthetic rate (B), water-use efficiency (C), and stomata conductance (D) of S. nigrum. Different letters show a significance difference at $p<0.05$ along with $n=4$.

\subsection{Assessment of Antioxidant Enzyme Activities and EL, MDA, and $\mathrm{H}_{2} \mathrm{O}_{2}$}

After N-fertilizer supplementation, a significant reduction was noticed in the MDA, $\mathrm{H}_{2} \mathrm{O}_{2}$, and electrolyte leakage parameters (Figure 4). Reductions in EL in the leaves of the urea, $\mathrm{NH}_{4} \mathrm{NO}_{3}$, and urea $+\mathrm{NH}_{4} \mathrm{NO}_{3}$ treated plants were $15 \%, 33 \%$, and $22 \%$, respectively, compared with the control plants. The catalase (CAT), peroxidase (POD), ascorbate peroxidase (APX), and superoxide dismutase (SOD) enzyme activities in the $S$. nigrum leaf were significantly increased after the addition of N-fertilizers (Figure 5). In contrast to the control group, the increases in the POD, CAT, APX, and SOD values of the $\mathrm{N}$-fertilized plants were $41 \%, 21 \%$, and $64 \% ; 47 \%, 22 \%$, and $66 \% ; 15 \%, 28 \%$, and $42 \%$; and $48 \%, 69 \%$, and $25 \%$, respectively. 

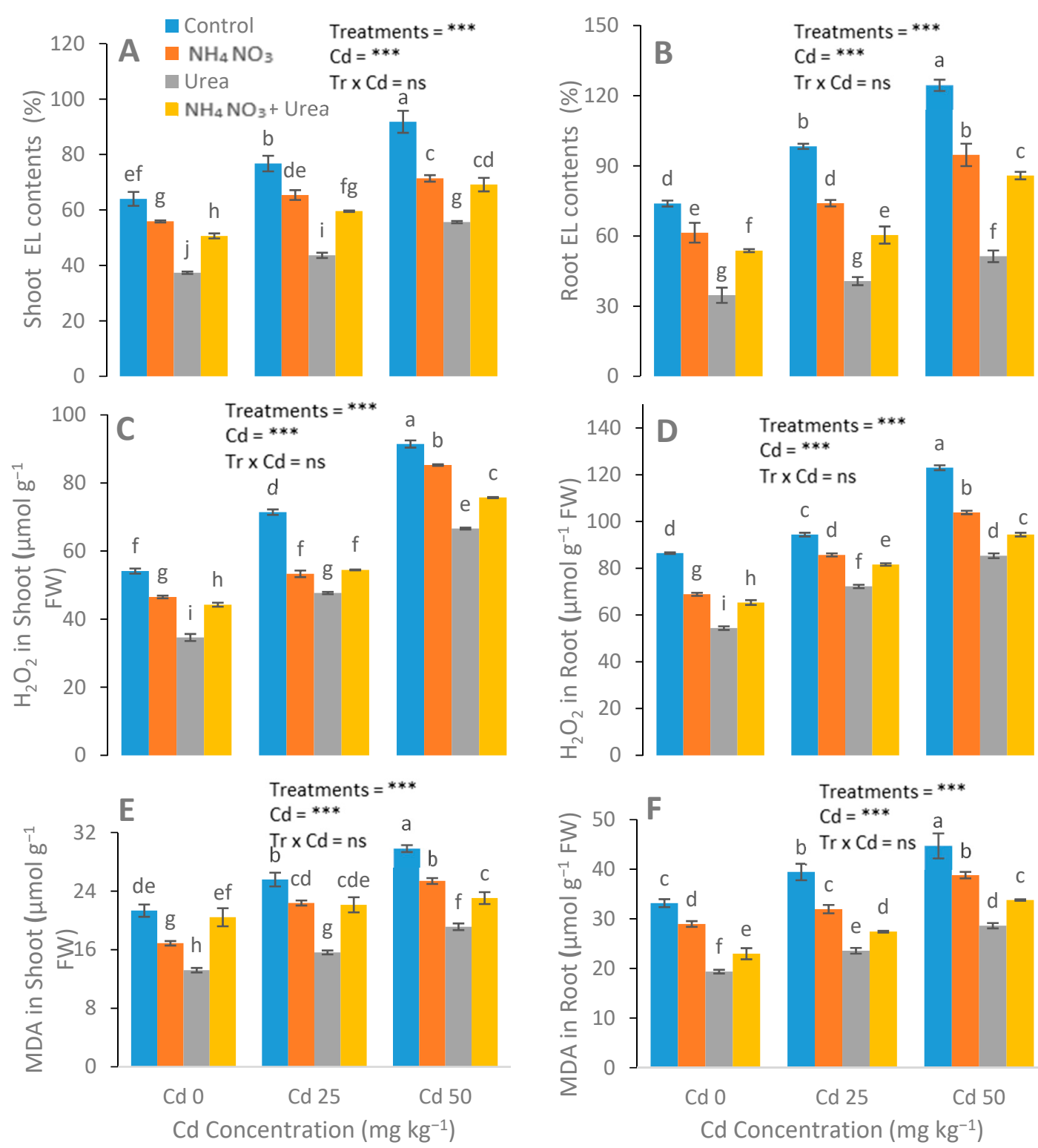

Figure 4. Effect of $\mathrm{Cd}\left(0,25\right.$, and $\left.50 \mathrm{mg} \mathrm{kg}^{-1}\right)$ and $\mathrm{N}$ fertilizers (ratios of 0:0, 100:0, 0:100, and 50:50 mg kg ${ }^{-1}$ urea, $\mathrm{NH}_{4} \mathrm{NO}_{3}$, and urea $+\mathrm{NH}_{4} \mathrm{NO}_{3}$ ) on electrolyte leakage (EL) in leaves (A), EL in roots (B), $\mathrm{H}_{2} \mathrm{O}_{2}$ in leaves (C), $\mathrm{H}_{2} \mathrm{O}_{2}$ in roots (D), malondialdehyde (MDA) in leaves (E), and MDA in the roots $(\mathbf{F})$ of $S$. nigrum. Different letters show a significance difference at $p<0.05$ along with $n=4$. 

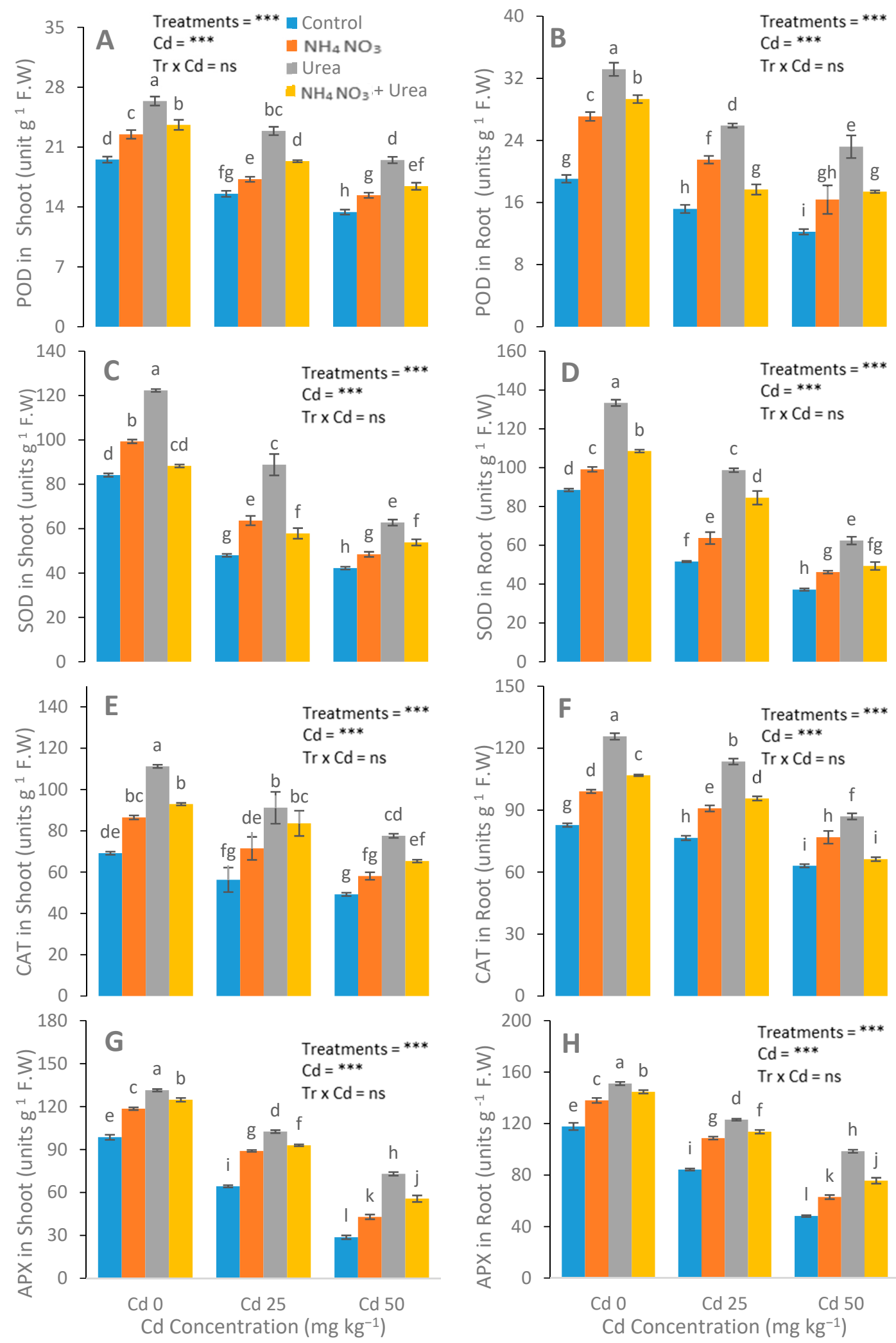

Figure 5. Effects of $\mathrm{Cd}\left(0,25\right.$, and $\left.50 \mathrm{mg} \mathrm{kg}^{-1}\right)$ and $\mathrm{N}$ fertilizers (levels $0-0,100-0,0-100$, and $50-50 \mathrm{mg} \mathrm{kg}^{-1}$ for urea, $\mathrm{NH}_{4} \mathrm{NO}_{3}$, and urea $+\mathrm{NH}_{4} \mathrm{NO}_{3}$ ) on POD in leaves (A), POD in roots (B), SOD in leaves (C), SOD in roots (D), CAT in leaves (E), CAT in roots (F), APX in leaves (G), and APX in roots (H) of S. nigrum. Different letters show a significance difference at $p<0.05$ along with $n=4$. 


\subsection{Assessment of Concentration of $\mathrm{Cd}$ in Plants}

The optimum induction of $\mathrm{N}$-fertilizers remarkably enhanced the $\mathrm{Cd}$ concentration in the roots and shoots of S. nigrum compared with the respective controls (Figure 6). In order to assess the phytoremediation potential of Cd by S. nigrum, the TF and BCF were calculated. Results showed that plants supplemented with urea had higher BCF when compared with other treatments.
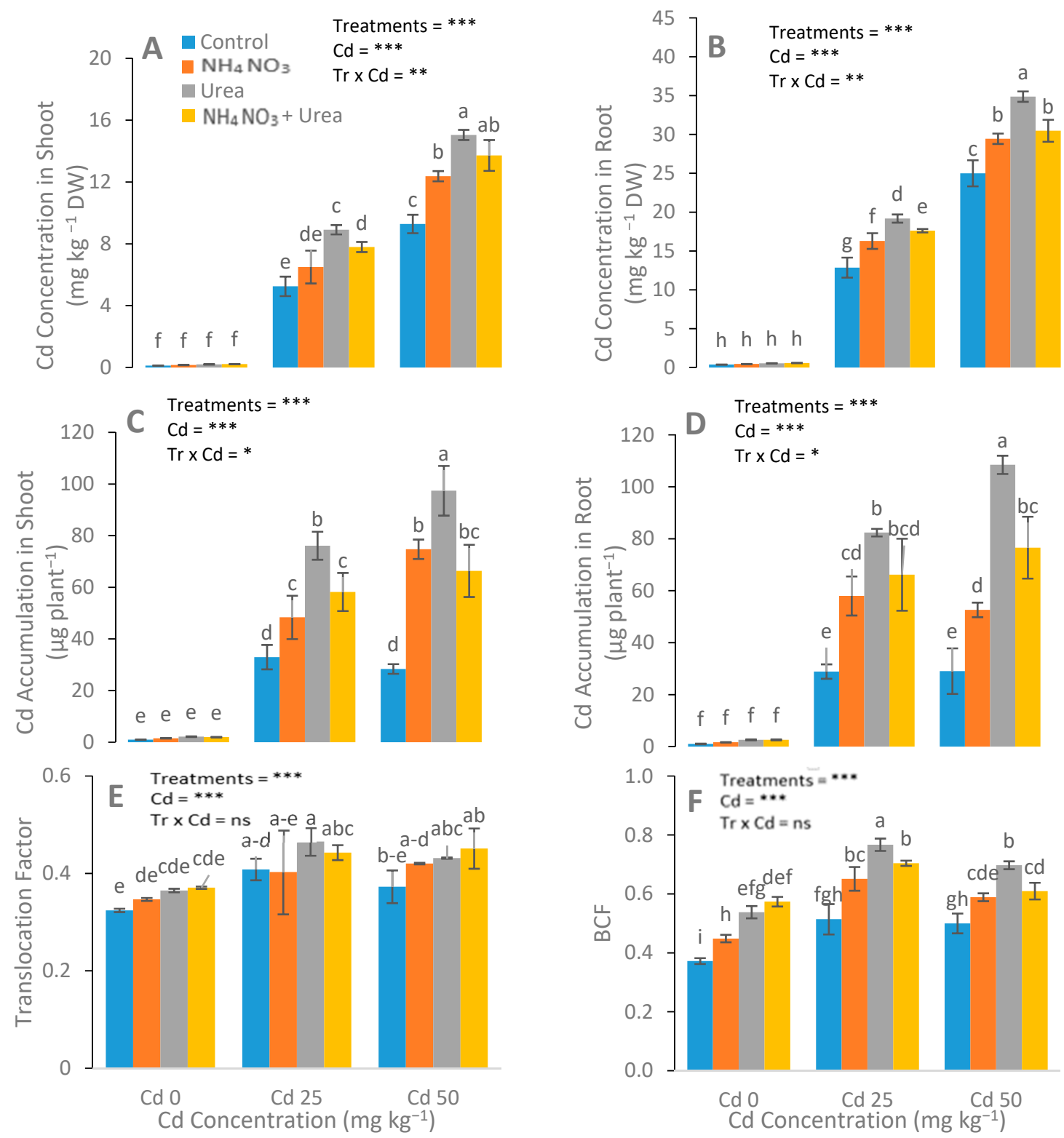

Figure 6. Effect of $\mathrm{Cd}$ stress (0, 25, and $\left.50 \mathrm{mg} \mathrm{kg}^{-1}\right)$ and $\mathrm{N}$ fertilizers (levels $0-0,100-0,0-100$, and 50-50 mg kg ${ }^{-1}$ for urea, $\mathrm{NH}_{4} \mathrm{NO}_{3}$, and urea $+\mathrm{NH}_{4} \mathrm{NO}_{3}$ ) on $\mathrm{Cd}$ uptake in shoots (A), Cd uptake in roots (B), Cd accumulation in shoots (C), Cd accumulation in roots (D) translocation factor (E) and bioaccumulation factor (BCF) (F) of S. nigrum. Different letters show a significance difference at $p<0.05$ along with $n=4$.

\section{Discussion}

\subsection{Biomass and Plant Growth}

It is an established fact that fertilizer application generally has positive effects on plant growth under heavy metal toxicity $[34,35]$. In the present study, the highest plant growth was observed 
in the urea-treated plants at $25 \mathrm{mg} \mathrm{kg}{ }^{-1} \mathrm{Cd}$ concentrations, in contrast to the $\mathrm{NH}_{4} \mathrm{NO}_{3}$-treated plants (Figure 1). The findings of our study are in accordance with the finding of Lin et al. [36], who found that $2.5 \mathrm{mmol} \mathrm{N} \mathrm{L}^{-1}$ was the optimal concentration to boost $S$. alfredii shoot growth. Moreover, $1.0 \mathrm{mmol} \mathrm{N} \mathrm{L}^{-1}$ was found to be an optimal concentration for $\mathrm{Cd}$ and $\mathrm{Zn}$ storage in the shoots of S. alfredii. Furthermore, stunted plant growth under heavy metal stress was noticed. For example, Rabelo et al. [37] reported that $2.0 \mathrm{mM} \mathrm{Cd}$ in Tanzania guinea grass inhibited the production of new tillers and leaves. A reduced nitrate uptake from the nutrient solution was reported by Gouia et al. [38] for Cd-exposed plants. It was investigated that the $\mathrm{Cd}$ concentration increased in S. nigrum with a supply of $\mathrm{N}$-fertilizer $\left(\mathrm{NH}_{4} \mathrm{NO}_{3}\right)$ without affecting the Cd speciation in plants [39]. Wei et al. [40] confirmed that the accretion of Cd in S. nigrum shoots and roots is augmented by applying urea in the growth medium. In our study, the root and shoot dry weights, shoot length, numbers of leaves per plant, and roots length of S. nigrum plants were significantly enhanced with the N-fertilizer application. In our current study, disparity in the $\mathrm{Cd}$ absorption in differently treated plants was observed, which is in line with the results of Ye et al. [41], who described an enhanced absorption of $\mathrm{Cd}$ and a phytoextraction efficiency of T. patula after N-fertilizer treatment. Moreover, our results are also supported by Yang et al. [42].

\subsection{Photosynthetic Pigments}

Maximum chlorophyll content was observed in the urea-treated plants at a $25 \mathrm{mg} \mathrm{kg}^{-1} \mathrm{Cd}$ concentration, compared with the $\mathrm{NH}_{4} \mathrm{NO}_{3}$-treated and control plants (Figure 2). Our results support the previous reports [43], in which the author claimed that different $\mathrm{N}$ forms, e.g., ammonium nitrate $\left(\mathrm{NH}_{4} \mathrm{NO}_{3}\right)$, ammonium sulfate $\left(\left(\mathrm{NH}_{4}\right)_{2} \mathrm{SO}_{4}\right)$, and calcium nitrate $\left(\mathrm{Ca}\left(\mathrm{NO}_{3}\right)_{2}\right)$, significantly altered the $\mathrm{Chl} a, \mathrm{Chl} b$, total $\mathrm{Chl}$, and carotenoid contents under Cd stress. Cadmium is a phytotoxic metal that causes growth inhibition. A high dose or prolonged exposure to $\mathrm{Cd}$ can lead to the death of plants, which is the result of disturbed respiration, reduced photosynthesis, and altered assimilation of $\mathrm{N}$ in plants [44]. Cadmium toxicity alters the $\mathrm{N}$ metabolism directly or indirectly [45]. It was found that an optimum $\mathrm{N}$ dosage may alleviate $\mathrm{Cd}$ toxicity to plants by improving the photosynthetic activity, stromal proteins, and the plant growth and biomass [46]. Under stress conditions, plants provoke antioxidant enzymes and certain metabolite activities for their survival in order to negate stress [47]. Jalloh et al. [48] reported that an appropriate dosage of urea and $\mathrm{NH}_{4}{ }^{+}-\mathrm{N}$ under $\mathrm{Cd}$ stress stimulated and increased the SOD and POD activities. Significantly increased MDA content in Cd-stressed plants were observed with addition of $\mathrm{NH}_{4}{ }^{+}-\mathrm{N}$ and/or urea in rice plants at the milking stage.

\subsection{Oxidative Stress, Antioxidant Enzymes, and Cd Concentration}

Malmir [49] found that Cr-induced oxidative stress, subsequently increasing the $\mathrm{H}_{2} \mathrm{O}_{2}$ and MDA contents. Similar evidence of Cr-induced oxidative stress was observed in Helianthus annuus L. [50] and Brassica. Various studies have shown that different amendments have reduced the Cd toxicity in different plant species, for example, EDTA reduced Cd toxicity in Brassica [51], silicon in Brassica napus L. [52], hydrogen peroxide in Brassica napus L. [53], supermine in Vigna radiate L. [54], and selenium in rapeseed seedlings [55]. The markedly reduced EL and MDA contents in the N-fertilizer-treated, $\mathrm{Cd}$-stressed plants in our study demonstrate the significant role of $\mathrm{N}$ fertilizers for $\mathrm{Cd}$ stress. Our results revealed that SOD, POD, CAT, and APX activities of S. nigrum were recorded in response to Cd stress. Furthermore, the POD, CAT, SOD, and APX activities significantly increased after the application of $\mathrm{N}$-fertilizers. Similar results were observed previously [43], indicating that $\mathrm{N}$ forms had a prominent impact on oxidative stress inflicted by $\mathrm{Cr}$ toxicity. Therefore, the $\mathrm{Ca}\left(\mathrm{NO}_{3}\right)_{2}$-fed plants had minimal oxidative stress compared with the $\left(\mathrm{NH}_{4}\right)_{2} \mathrm{SO}_{4}$ and urea-treated plants.

Similar findings were observed for the $\mathrm{N}$ fertilizers for the phytoremediation of $\mathrm{Cd}$, and even with different environmental conditions, soil textures, and experimental durations [56], and only a few analyses, we acknowledged the possible mechanisms for $\mathrm{Cd}$ phytoremediation with detailed analysis in our recent study. In addition, urea-treated plants translocated and accumulated a higher 
concentration of $\mathrm{Cd}$ than the $\mathrm{NH}_{4} \mathrm{NO}_{3}$-treated plants. However, the application of $\mathrm{N}$-fertilizers inhibited oxidative damage and enhanced antioxidants' enzyme activities. Our results depicted that at all levels of applied Cd, the both TF and BCF were enhanced with the application of urea alone, as compared with all other treatments (Figure $6 \mathrm{E}, \mathrm{F}$ ). This shows that among the various treatments, the plants treated with urea alone had greater potential for $\mathrm{Cd}$ phytoremediation. In conclusion, the suitable concentration of urea remarkably promoted and assisted the processes of $\mathrm{Cd}$ phytoremediation by S. nigrum.

\section{Conclusions}

Our study concludes that the application of an appropriate dosage of $\mathrm{N}$ fertilizers $\left(\mathrm{NH}_{4} \mathrm{NO}_{3}\right.$ and urea) could be a suitable practice to enhance the remediation of heavy-metal-polluted soils when growing S. nigrum. The plant biomass increased significantly with $\mathrm{N}$ fertilizer addition. Maximum plant growth was observed in the urea-treated plants compared with the $\mathrm{NH}_{4} \mathrm{NO}_{3}$-treated plants. In addition, the urea-treated plants also accumulated a higher $\mathrm{Cd}$ than the $\mathrm{NH}_{4} \mathrm{NO}_{3}$-treated plants. The application of $\mathrm{N}$ fertilizers inhibited oxidative stress and enhanced the antioxidants' enzymatic activities. It is concluded that urea might be helpful for better growth of S. nigrum under Cd stress. Our results indicate that the best $\mathrm{N}$-fertilizer is urea, and that it is recommended for the phytoremediation of $\mathrm{Cd}$. However, the application of urea for heavy metals phytoremediation other than $\mathrm{Cd}$ is still unknown, and future studies can be helpful for this investigation.

Author Contributions: Conceptualization, A.M., S.A. (Shafaqat Ali), T.Y., S.N., S.A. (Saad Alkahtani), and M.M.A.-D.; Data curation, A.M., M.R. (Muhammad Riaz), and A.H.; Formal analysis, A.M., M.R. (Muhammad Rizwan), and A.H.; Funding acquisition, S.A. (Saad Alkahtani) and M.M.A.-D.; Investigation, M.R. (Muhammad Riaz); Methodology, A.M., T.Y., M.R. (Muhammad Riaz), A.H., and S.N.; Project administration, S.A. (Shafaqat Ali) and S.A. (Saad Alkahtani); Resources, S.A. (Saad Alkahtani) and M.M.A.-D.; Software, M.R. (Muhammad Rizwan), M.S.A., and A.H.; Supervision, S.A. (Shafaqat Ali); Validation, M.R. (Muhammad Rizwan) and M.S.A.; Visualization, M.S.A. and S.N.; Writing-original draft, A.M., A.H., and S.N.; Writing-review and editing, S.A. (Shafaqat Ali), T.Y., S.A. (Saad Alkahtani), and M.M.A.-D. All authors have read and agreed to the published version of the manuscript.

Funding: This work was also funded by the Researchers Supporting Project (RSP 2019/26), King Saud University, Riyadh, Saudi Arabia.

Acknowledgments: The authors are highly thankful to the Government College University Faisalabad-38000, Pakistan. This work was also funded by the Researchers Supporting Project (RSP 2019/26), King Saud University, Riyadh, Saudi Arabia.

Conflicts of Interest: The authors declare no conflict of interest.

\section{References}

1. Goldstone, J.A. Demography, environment, and security. Environ. Confl. Routledge 2018, 8, 84-108.

2. Murtaza, G.; Javed, W.; Hussain, A.; Wahid, A.; Murtaza, B.; Owens, G. Metal uptake via phosphate fertilizer and city sewage in cereal and legume crops in Pakistan. Environ. Sci. Pollut. Res. 2015, 22, 9136-9147. [CrossRef] [PubMed]

3. Markovic, J.; Jovic, M.; Smiciklas, I.; Sljivic-Ivanovic, M.; Onjia, A.; Trivunac, K.; Popovic, A. Cadmium retention and distribution in contaminated soil: Effects and interactions of soil properties, contamination level, aging time and in situ immobilization agents. Ecotoxicol. Environ. Saf. 2019, 174, 305-314. [CrossRef] [PubMed]

4. Rizwan, M.; Ali, S.; Adrees, M.; Ibrahim, M.; Tsang, D.C.; Rehman, M.Z.; Zahir, Z.A.; Rinklebe, J.; Tack, F.M.; Ok, Y.S. A critical review on effects, tolerance mechanisms and management of cadmium in vegetables. Chemosphere 2017, 182, 90-105. [CrossRef] [PubMed]

5. Ali, B.; Gill, R.A.; Yang, S.; Gill, M.B.; Ali, S.; Rafiq, M.T.; Zhou, W. Hydrogen sulfide alleviates cadmium-induced morpho-physiological and ultrastructural changes in Brassica napus. Ecotoxicol. Environ. Saf. 2014, 110, 197-207. [CrossRef] [PubMed]

6. Nagajyoti, P.C.; Lee, K.D.; Sreekanth, T.V.M. Heavy metals, occurrence and toxicity for plants: A review. Environ. Chem. Lett. 2010, 8, 199-216. [CrossRef] 
7. Rehman, M.Z.; Khalid, H.; Akmal, F.; Ali, S.; Rizwan, M.; Qayyum, M.F.; Iqbal, M.; Khalid, M.U.; Azhar, M. Effect of limestone, lignite and biochar applied alone and combined on cadmium uptake in wheat and rice under rotation in and effluent irrigated field. Environ. Pollut. 2017, 227, 560-568. [CrossRef]

8. Gill, R.A.; Ali, B.; Islam, F.; Farooq, M.A.; Gill, M.B.; Mwamba, T.M.; Zhou, W. Physiological and molecular analyses of black and yellow seeded Brassica napus regulated by 5 -aminolivulinic acid under chromium stress. Plant Physiol. Biochem. 2015, 94, 130-143. [CrossRef]

9. Xia, S.; Song, Z.; Jeyakumar, P.; Shaheen, S.M.; Rinklebe, J.; Ok, Y.S.; Wang, H. A critical review on bioremediation technologies for $\mathrm{Cr}(\mathrm{VI})$-contaminated soils and wastewater. Critic. Rev. Environ. Sci. Technol. 2019, 49, 1027-1078. [CrossRef]

10. Deng, Z.; Cao, L. Fungal endophytes and their interactions with plants in phytoremediation: A review. Chemosphere 2017, 168, 1100-1106. [CrossRef]

11. Bączek-Kwinta, R.; Juzoń, K.; Borek, M.; Antonkiewicz, J. Photosynthetic response of cabbage in cadmium-spiked soil. Photosynthetica 2019, 57, 731-739. [CrossRef]

12. Ji, P.H.; Song, Y.F.; Jiang, Y.; Tang, X.; Tong, Y.A.; Gao, P.; Han, W. A two-year field study of phytoremediation using Solanum nigrum L. in China. Int. J. Phytorem. 2016, 18, 924-928. [CrossRef] [PubMed]

13. Wu, M.X.; Luo, Q.; Liu, S.L.; Zhao, Y.; Long, Y.; Pan, Y.Z. Screening ornamental plants to identify potential Cd hyperaccumulators for bioremediation. Ecotoxicol. Environ. Saf. 2018, 162, 35-41. [CrossRef] [PubMed]

14. Dai, H.; Wei, S.; Twardowska, I.; Han, R.; Xu, L. Hyperaccumulating potential of Bidens pilosa L. for Cd and elucidation of its translocation behavior based on cell membrane permeability. Environ. Sci. Pollut. 2017, 24, 23161-23167. [CrossRef]

15. Jacobs, A.; Noret, N.; Van Baekel, A.; Liénard, A.; Colinet, G.; Drouet, T. Influence of edaphic conditions and nitrogen fertilizers on cadmium and zinc phytoextraction efficiency of Noccaea caerulescens. Sci. Total Environ. 2019, 665, 649-659. [CrossRef]

16. Li, T.Q.; Di, Z.Z.; Yang, X.E.; Sparks, D.L. Effects of dissolved organic matter from the rhizosphere of the hyperaccumulator Sedum alfredii on sorption of zinc and cadmium by different soils. J. Hazard. Mater. 2011, 192, 1616-1622. [CrossRef]

17. Álvarez-Mateos, P.; Alés-Álvarez, F.J.; García-Martín, J.F. Phytoremediation of highly contaminated mining soils by Jatropha curcas L. and production of catalytic carbons from the generated biomass. J. Environ. Manag. 2019, 231, 886-895. [CrossRef]

18. Li, Y.C.; Li, Y.F.; Chang, S.X.; Yang, Y.F.; Fu, S.L.; Jiang, P.K.; Luo, Y.; Yang, M.; Chen, Z.H.; Hu, S.D.; et al. Biochar reduces soil heterotrophic respiration in a subtropical plantation through increasing soil organic carbon recalcitrancy and decreasing carbon-degrading microbial activity. Soil Biol. Biochem. 2018, 122, 173-185. [CrossRef]

19. Pan, H.; Xie, K.; Zhang, Q.; Jia, Z.; Xu, J.; Di, H.; Li, Y. Archaea and bacteria respectively dominate nitrification in lightly and heavily grazed soil in a grassland system. Biol. Fertil. Soils 2018, 54, 41-54. [CrossRef]

20. Xiao, M.L.; Zang, H.D.; Liu, S.L.; Ye, R.Z.; Zhu, Z.K.; Su, Y.R.; Wu, J.S.; Ge, T.D. Nitrogen fertilization alters the distribution and fates of photosynthesized carbon in rice-soil systems: A $13 \mathrm{C}-\mathrm{CO}_{2}$ pulse labeling study. Plant Soil 2019, 445, 101-112. [CrossRef]

21. Arnamwong, S.; Wu, L.H.; Hu, P.J.; Yuan, C.; Thiravetyan, P.; Luo, Y.M.; Christie, P. Phytoextraction of cadmium and zinc by Sedum plumbizincicola using different nitrogen fertilizers, a nitrification inhibitor and a urease inhibitor. Int. J. Phytorem. 2015, 17, 382-390. [CrossRef] [PubMed]

22. Liu, H.; Ding, Y.; Zhang, Q.; Liu, X.; Xu, J.; Li, Y.; Di, H. Heterotrophic nitrification and denitrification are the main sources of nitrous oxide in two paddy soils. Plant Soil 2018, 445, 39-53. [CrossRef]

23. Yang, Z.B.; Liu, L.X.; Lv, Y.F.; Cheng, Z.; Xu, X.X.; Xian, J.R.; Zhu, X.M.; Yang, Y.X. Metal availability, soil nutrient, and enzyme activity in response to application of organic amendments in Cd-contaminated soil. Environ. Sci. Pollut. Res. 2018, 25, 2425-2435. [CrossRef] [PubMed]

24. Yavari, S.; Malakahmad, A.; Sapari, N.B.; Yavari, S. Nutrients balancefor improvement of phytoremediation ability of teak seedlings (Tectona grandis). J. Plant Nutr. 2018, 41, 545-551. [CrossRef]

25. Liu, Y.L.; Ge, T.D.; Jun, Y.; Liu, S.L.; Shibistova, O.; Wang, P.; Wang, J.K.; Li, Y.; Guggenberger, G.; Kuzyakov, Y.; et al. Initial utilization of rhizodeposits with rice growth in paddy soils: Rhizosphere and $\mathrm{N}$ fertilization effects. Geoderma. Res. 2019, 338, 30-39. [CrossRef] 
26. Yang, W.; Dai, H.; Skuza, L.; Wei, S. Strengthening role and the mechanism of optimum nitrogen addition in relation to Solanum nigrum L. Cd hyperaccumulation in soil. Ecotoxicol. Environ. saf. 2019, 182, 109444. [CrossRef]

27. Bouyoucos, G.J. Hydrometer method improved for making particle size analyses of soils. Agron. J. 1962, 54, 464-465. [CrossRef]

28. Jackson, M.L. Soil Chemical Analysis; Constable and Co. Ltd.: London, UK, 1962; p. 219.

29. Page, A.L.; Miller, R.H.; Keeny, D.R. Methods of Soil Analysis (Part 2). In Chemical and Microbiological Properties; SSSA: Madison, WI, USA, 1982; Volume 9.

30. Lichtenthaler, H.K. Chlorophylls and carotenoids pigments of photosynthetic biomembranes. In Methods in Enzymology; Colowick, S.P., Kaplan, N.O., Eds.; Academic Press: Cambridge, MA, USA, 1987; Volume 148, pp. 350-382.

31. Dionisio-Sese, M.L.; Tobita, S. Antioxidant responses of rice seedlings to salinity stress. Ecosyst. Environ. Res. 1998, 253, 122-130. [CrossRef]

32. Zhang, X.Z. The measurement and mechanism of lipid peroxidation and SOD, POD and CAT activities in biological system. In Research Methodology of Crop Physiology; Agriculture Press: Beijing, China, 1992; pp. 208-211.

33. Aebi, H. Catalase in vitro. Methods Enzymol. 1984, 105, 121-126.

34. Zhang, R.R.; Liu, Y.; Xue, W.L.; Chen, R.X.; Du, S.T.; Jin, C.W. Slow release nitrogen fertilizers can improve yield and reduce Cd concentration in pakchoi (Brassica chinensis L.) grown in Cd contaminated soil. Environ. Sci. Pollut. Res. 2016, 23, 25074-25083. [CrossRef]

35. Zhou, G.D.; Guo, J.M.; Yang, J.; Yang, J.X. Effect of fertilizers on Cd accumulation and subcellular distribution of two cosmos species (Cosmos sulphureus and Cosmos bipinnata). Int. J. Phytorem. Res. 2018, 20, 930-938. [CrossRef] [PubMed]

36. Lin, Z.; Dou, C.; Li, Y.; Wang, H.; Niazi, N.K.; Zhang, S.; Ye, Z. Nitrogen fertilizer enhances zinc and cadmium uptake by hyperaccumulator Sedum alfredii Hance. J. Soils Sediments 2019, 20, 320-329. [CrossRef]

37. Rabelo, F.H.S.; Azevedo, R.A.; Monteiro, F.A. Proper supply of $S$ increases GSH synthesis in the establishment and reduces tiller mortality during the regrowth of Tanzania guinea grass used for Cd phytoextraction. J. Soils Sediments. Res. 2017, 17, 1427-1436. [CrossRef]

38. Gouia, H.; Ghorbala, M.H.; Meyer, C. Effects of cadmium on activity of nitrate reductase and on other enzymes of the nitrate assimilation pathway in bean. Plant Physiol. Biochem. Res. 2000, 38, 629-638. [CrossRef]

39. Cheng, M.; Wang, P.; Kopittke, P.M.; Wang, A.; Sale, P.W.; Tang, C. Cadmium accumulation is enhanced by ammonium compared to nitrate in two hyperaccumulators, without affecting speciation. J. Exp. Bot. 2016, 67, 5041-5050. [CrossRef] [PubMed]

40. Wei, S.; Li, Y.; Zhou, Q.; Srivastava, M.; Chiu, S.; Zhan, J.; Wu, Z.; Sun, T. Effect of fertilizer amendments on phytoremediation of $\mathrm{Cd}$-contaminated soil by a newly discovered hyperaccumulator Solanum nigrum $\mathrm{L}$. J. Hazard. Mater. 2010, 176, 269-273. [CrossRef]

41. Ye, X.; Hu, H.; Li, H.; Xiong, Q.; Gao, H. Combined nitrogen fertilizer and wheat straw increases the cadmium phytoextraction efficiency of Tagetes patula. Ecotoxicol. Environ. Saf. 2019, 170, 210-217. [CrossRef]

42. Yang, W.; Dai, H.; Dou, X.; Zhang, Q.; Wei, S. Effect and mechanism of commonly used four nitrogen fertilizers and three organic fertilizers on Solanum nigrum L. hyperaccumulating Cd. Environ. Sci. Pollut. Res. 2019, 26, 12940-12947. [CrossRef]

43. Hassan, M.J.; Zhang, G.; Zhu, Z. Influence of cadmium toxicity on plant growth and nitrogen uptake in rice as affected by nitrogen form. J. Plant Nutr. 2008, 3, 251-262. [CrossRef]

44. Sanita, L.; Di Toppi, S.; Gabbrielli, R. Response to cadmium in higher plants. Environ. Exp. Bot. 1999, 41, 105-130. [CrossRef]

45. Kastori, R.; Petrovic, N.; Arsenijevic-Maksimovic, I. Heavy metals and plants. In Heavy Metals in the Environment; Kastori, R., Ed.; Feljton: Novi Sad, Serbia, 1997; pp. 195-257.

46. Pakovic, D.; Plesnicar, M.; Arsenijevic-Marksimovic, I.; Petrovic, N. Effects of nitrogen nutrition on photosynthesis in Cd-treated plants. Ann. Bot. 2000, 86, 841-847. [CrossRef]

47. Foyer, C.H.; Descourviers, P.; Kunert, K.J. Protection against oxygen radicals: An important defense mechanism studied in transgenic plants. Plant Cell Environ. Res. 1994, 17, 507-523. [CrossRef] 
48. Jalloh, M.A.; Chen, J.; Zhen, F.; Zhang, G. Effect of different $\mathrm{N}$ fertilizer forms on antioxidant capacity and grain yield of rice growing under Cd stress. J. Hazard. Mater. 2009, 162, 1081-1085. [CrossRef]

49. Malmir, H.A. Comparison of antioxidant enzyme activities in leaves stems and roots of Sorghum (Sorghum bicolor L.) exposed to Chromium (VI). Afr. J. Plant Sci. 2011, 5, 436-444.

50. Gallego, S.M.; Pena, L.B.; Barcia, R.A.; Azpilicueta, C.E.; Iannone, M.F.; Rosales, E.P.; Zawoznik, M.S.; Groppa, M.D.; Benavides, M.P. Unravelling cadmium toxicity and tolerance in plants: Insight into regulatory mechanisms. Environ. Exp. Bot. 2012, 83, 33-46. [CrossRef]

51. Pandey, V.; Dixit, V.; Shyam, R. Antioxidative responses in relation to growth of mustard (Brassica juncea cv. Pusa Jaikisan) plants exposed to hexavalent chromium. Chemosphere 2005, 61, 40-47. [CrossRef]

52. Mahmud, J.A.; Hasanuzzaman, M.; Nahar, K.; Rahman, A.; Fujita, M. EDTA reduces cadmium toxicity in mustard (Brassica juncea L.) by enhancing metal chelation, antioxidant defense and glyoxalase systems. Acta Agrobot. 2019, 72, 1722. [CrossRef]

53. Hasanuzzaman, M.; Nahar, K.; Anee, T.I.; Fujita, M. Exogenous silicon attenuates cadmium-induced oxidative stress in Brassica napus L. by modulating AsA-GSH pathway and glyoxalase system. Front. Plant Sci. 2017, 8, 1061. [CrossRef]

54. Hasanuzzaman, M.; Nahar, K.; Gill, S.S.; Alharby, H.F.; Razafindrabe, B.H.; Fujita, M. Hydrogen peroxide pretreatment mitigates cadmium-induced oxidative stress in Brassica napus L.: An intrinsic study on antioxidant defense and glyoxalase systems. Front. Plant Sci. 2017, 8, 115. [CrossRef]

55. Nahar, K.; Rahman, M.; Hasanuzzaman, M.; Alam, M.M.; Rahman, A.; Suzuki, T.; Fujita, M. Physiological and biochemical mechanisms of spermine-induced cadmium stress tolerance in mung bean (Vigna radiata L.) seedlings. Environ. Sci. Pollut. Res. 2016, 23, 21206-21218. [CrossRef]

56. Hasanuzzaman, M.; Hossain, M.A.; Fujita, M. Exogenous selenium pretreatment protects rapeseed seedlings from cadmium-induced oxidative stress by upregulating antioxidant defense and methylglyoxal detoxification systems. Biol. Trace Element Res. 2012, 149, 248-261. [CrossRef] [PubMed]

(C) 2020 by the authors. Licensee MDPI, Basel, Switzerland. This article is an open access article distributed under the terms and conditions of the Creative Commons Attribution (CC BY) license (http://creativecommons.org/licenses/by/4.0/). 